\title{
New geographical records and key to the species of Eumerus Meigen, 1823 (Diptera, Syrphidae) introduced into the Americas and Hawaii
}

\author{
Bolívar R. Garcete-Barrett ${ }^{1,2}$ (D), Mírian N. Morales ${ }^{3}$ (D), Martin Hauser ${ }^{4}$ (D),

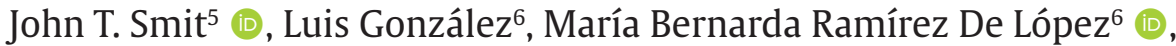 \\ Osmar Arias $^{6}\left({ }^{0}\right.$, Marcial Adorno ${ }^{6}$, Gerald Sormanti ${ }^{6}$, Adriana Mereles ${ }^{6}$ \\ ${ }^{1}$ Museo Nacional de Historia Natural del Paraguay, San Lorenzo, Paraguay. \\ ${ }^{2}$ Universidad Nacional de Asunción, Facultad de Ciencias Exactas y Naturales, Departamento de Biología c/o Dirección de \\ Investigación, San Lorenzo, Paraguay. \\ ${ }^{3}$ Universidade Federal de Lavras, Departamento de Entomologia, Lavras, MG, Brasil. \\ ${ }^{4}$ California Department of Food and Agriculture, Plant Pest Diagnostics, Sacramento, USA. \\ ${ }^{5}$ European Invertebrate Survey - the Netherlands, Naturalis Biodiversity Center, Leiden, the Netherlands. \\ ${ }^{6}$ Universidad Nacional de Asunción, Facultad de Ciencias Agrarias, Departamento de Protección Vegetal, Carrera de Ingeniería \\ Agronómica, San Lorenzo, Paraguay.
}

\section{A R T I C L E I N F O}

\section{Article history:}

Received 04 February 2019

Accepted 23 December 2019

Available online 13 March 2020

Associate Editor: Marcia Couri

\section{Keywords:}

Hover flies

Identification key

Invasive species

Pest insects

\begin{abstract}
A B S T R A C T
Eumerus Meigen, 1823 is a very speciose genus of flower flies from the Eastern Hemisphere. Several reports of introduced species of this genus in the Americas have been recorded since early in the twentieth century, with a present list of six species recorded to date from the Americas and the US territory of Hawaii. In this paper we give new geographical records for the African-native species Eumerus obliquus (Fabricius, 1805), which reflect the expansion of this fly through Brazil and Paraguay along the last twenty years. At the same time, we report a second species from Paraguay, Eumerus aurifrons (Wiedemann, 1824), being this the first Western Hemisphere record for this Asian-native species. We finally provide an identification key to all of the species of Eumerus presently known from the Americas and Hawaii.
\end{abstract}

\section{Introduction}

Eumerus Meigen, 1822, is one of the largest genera of flower flies (Diptera: Syrphidae), including nearly 300 species currently recognized (Thompson, 2018). It is primarily distributed throughout the Old World, with most of its species naturally occurring in the Palearctic (over 170 spp.) and Afrotropical (77 spp.) regions (Peck, 1988; Kuznetzov, 1992; Whittington, 2003; Speight et al., 2013; Grković et al., 2015; Ricarte et al., 2017).

The genus belongs to the tribe Merodontini (Eristalinae)(Young et al., 2016), and unlike most Eristalinae whose larvae are mainly saprophagous, species of Eumerus and few other genera (e.g.: Alipumilio Shannon,

\footnotetext{
* Corresponding author.

E-mail: john.smit@naturalis.nl (J.T. Smit).
}

Cheilosia Meigen, Merodon Meigen, Portevinia Goffe) are phytophagous. There are records of Eumerus larvae feeding on living bulbs, tubers, stems, rhizomes, and decaying vegetal tissue (Ricarte et al., 2017, and references therein).

Because of their feeding behavior, associated with commercialized plants, some species have been unintentionally transported by human trade outside their natural ranges and are now causing damage to crops in their new range. In the Americas four species have been introduced so far, three from the Nearctic region: Eumerus funeralis Meigen, E. narcissiSmith and E. strigatus (Fallén) (Johnson, 1910; Gibson, 1917; Jones, 1917; Weiss and Nicolay, 1919; Mackie, 1922; Smith, 1928; Wirth et al., 1965; Miranda et al., 2013; Speight et al., 2013). Two of those species have also been introduced in the neotropics: E. funeralis 
was recorded from Colombia (Thompson et al., 1976; Montoya, 2016), and E. strigatus from Chile (Gerding et al., 1999). The fourth species, E. obliquus (Fabricius), has been recorded from Brazil (Marinoni and Morales, 2007; Morales and Marinoni, 2019) Additionally two species have been recorded from Hawaii: Eumerus aurifrons(Wiedemann) and E. figurans Walker (Fullaway and Krauss, 1945; Carter, 1968; Asquith and Messing, 1993).

Recent fieldwork in Paraguay yielded material of two species of Eumerus (Figs. 1 and 2), extending the known distribution of $E$. obliquus within South America from Brazil into Paraguay and representing the first record of E. aurifrons for South America. During 2016 and 2017 the FCAPY carried out an insect fauna inventory on bean plots (Phaseolus vulgaris L.) at the locality of Choré, San Pedro, Paraguay. The plots were surrounded by small fragments of the semideciduous inner Atlantic forest, which dominated most of Eastern Paraguay decades ago. Yellow pan traps were the selected method and a number of Eumerus specimens, belonging to two different species, were collected. Additional specimens have been found in 2018 at Ybycui National Park, placed about $200 \mathrm{~km}$ away from the previous locality and mainly covered with semideciduous inner Atlantic forest.

Here we present the new data from Paraguay, provide distribution of Eumerus obliquus in South America over time, record E. aurifrons for the Americas for the first time, illustrate the most salient morphological differences between these species and give an identification key to the six introduced species in the Americas and Hawaii.

\section{Material and methods}

The following acronyms are herein used for depositary scientific institutions of the listed material:

CCT-UFMG: Centro de Coleções Taxonômicas, Universidade Federal de Minas Gerais, Belo Horizonte, MG, Brazil.

CEUFLA: Coleção Entomológica da Universidade Federal de Lavras, Lavras, MG, Brazil.

DZUB: Coleção Entomológica do Departamento de Zoologia, Instituto de Ciências Biológicas da Universidade de Brasília, Brasília, DF, Brazil.

DZUP: Coleção Entomológica Pe. Jesus Santiago Moure, Universidade Federal do Paraná, Curitiba, PR, Brazil.

FCAPY: Facultad de Ciencias Agrarias, Universidad Nacional de Asunción, San Lorenzo, Paraguay

LACM: Los Angeles County Museum, Los Angeles, California, USA. MNHN: Muséum National d'Histoire Naturelle, Paris, France.

MNHNPY: Museo Nacional de Historia Natural del Paraguay, San Lorenzo, Paraguay.

NMB: Naturhistorisches Museum Basel, Basel, Switzerland.

RMNH: Naturalis Biodiversity Center, Leiden, the Netherlands.

ZMUC: Zoological Museum, University of Copenhagen, Copenhagen, Denmark.

\section{Results}

\section{Eumerus obliquus (Fabricius)}

Milesia obliqua Fabricius, 1805 (Holotype ZMUC00026496: http://daim. snm.ku.dk/digitized-type-collection-details-simple?catno=zmuc00026496). Type locality: "Guinea".

Eumerus cilitarsis Loew, 1848. Type-locality: "angeblich Oestreich" (Austria).

Eumerus crassitarsis Costa, 1885: Rendiconto dell' Accademia delle Scienze Fisiche e Matematiche, Napoli, 23(12): 173 and Atti della Reale Accademia delle Scienze Fisiche e Matematiche di Napoli, (2a)
2(13): 30 and Bollettino della Società Entomologica Italiana, 17(1885): 254 (Eumerus). Type-localities: "vicinanze di Oristano e ... campagna di Samassi" [= Oristano and Samaxis: Sardinia] (Italy).

Eumerus lugens Wiedemann, 1830. Type-locality: "Sct. Helena”

Distribution: AFRICA: Angola, Cape Verde Islands, Ghana, Guinea-Bissau, Kenya, Madagascar, Mauritius, Nigeria, Rhodesia, St. Helena, Senegal, Sierra Leone, South Africa, Tanzamia, Uganda, Zaire; EUROPE: Canary Islands, Corfu, Sardinia; MIDDLE EAST: Yemen; OCEANIA: Australia; SOUTH AMERICA: Brazil, Paraguay* (Paramonov, 1957; Peck, 1988; Barkemeyer, 2002; Marinoni and Morales, 2007; Grković et al., 2015; Thompson and Vockeroth, 2016; Ricarte et al., 2017; Smit et al., 2017).

Material examined: PARAGUAY: San Pedro: Choré, XII.2016-I.2017, from beans plot (FCA) [8 females and 5 males: MNHNPY; 8 females and 5 males: FCAPY; 1 female and 1 male: CEUFLA]; Santa Rosa, Laguna Blanca, $23^{\circ} 48^{\prime} 00.2^{\prime \prime}$ S 56 $16^{\circ} 27.3^{\prime \prime}$, W 8.I-29.I.2011, mainly from cerrado vegetation [8 females and 7 males: RMNH]; Paraguarí: Parque Nacional Ybycuí, 18.VIII.2018 (B. Garcete) [1 female and 3 males: MNHNPY]. BRAZIL: Paraná: Morretes, 24.II.1990, Zanella, F. leg [1 male, DZUP]; Minas Gerais: Belo Horizonte, Estação Ecológica UFMG. 17.VI.1998. D. Yanega (col.), UFMG idi 1300011 [1 male: CCT-UFMG]; nr. Timoteo, 15.-31.Mar.1999, Eurico R. DePaula [1 male: LACM]; Ingaí, Reserva Biológica do Boqueirão, 1050-1059m, 20.VII.2013, 2120'44"S / 4459'29”W., M.N.Morales (leg.) [1 female: CEUFLA]; Lavras, campus UFLA, 21¹3'58”S / 04459'39"W, $842 \mathrm{~m}$, leg. A. Ssymank, 08.IX.2017 [2 females: CEUFLA]; Mato Grosso

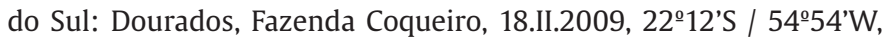
438m, Grossi \& Parizotto cols. [1 female: CEUFLA]; Distrito Federal: Gama, XI.2016, Savino AG (col.), 1559'15.5”S / 4806’10.5”W, Malaise trap [1 male: DZUB].

Illustrations: Both female (Fig. 1A) and male (Fig. 1B) are illustrated. Characters to separate it from Eumerus aurfrons are the abdominal pattern, (Fig. 1C), as well as the pattern of mesonotal pollinosity (Fig. 2A). Males have the eyes holoptic (Fig. 2B) and the hind tarsus is laterally compressed (Fig. 2C). In the female the scutellar rim is not serrate (Fig. 1D).

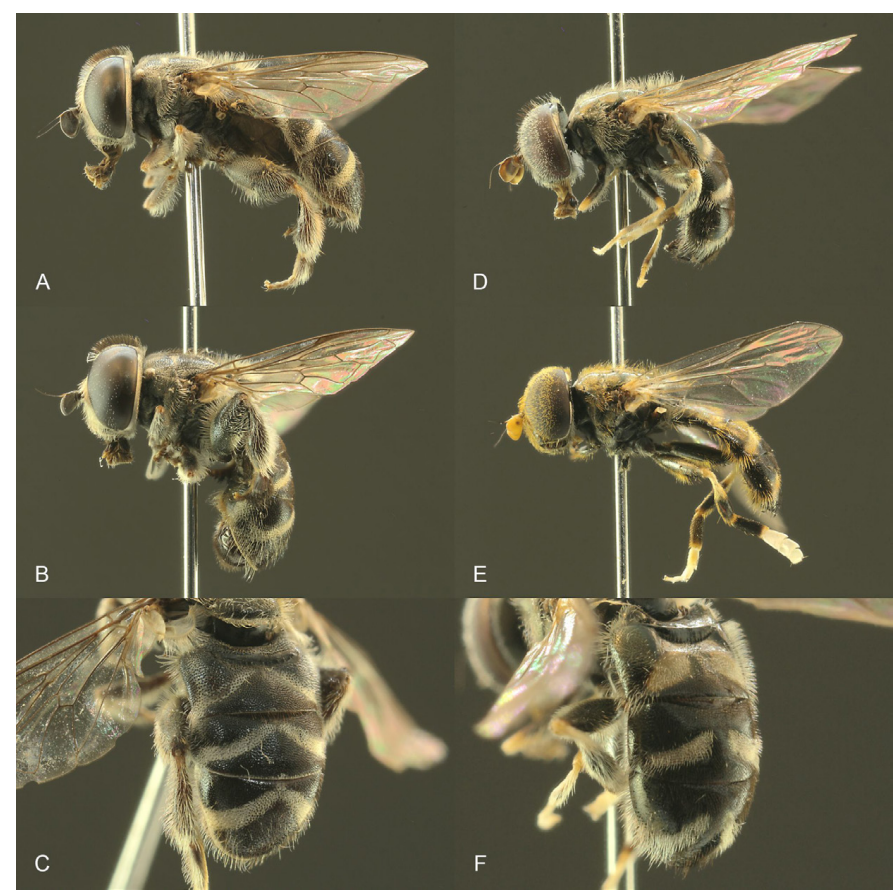

Figure 1. Eumerus species. A-C Eumerus obliquus (Fabricius). D-F Eumerus aurifrons (Wiedemann). A, C, D, F Female. B, E Male. A, B, D, E Habitus. C, F Abdomen in latero-dorsal view. 
Comments: The original description by Fabricius (1805: 194) establishes the provenance of the type material: "Habitat in Guinea Mus. Dom. Lund". According to Zimsen (1964), Tønder Lund's collection was one of the most important ones studied by Fabricius. Tønder Lund and his pupil Ove Sehested held high posts in the Civil Service of Denmark and amassed an important joint collection of insects through their official contacts in the Danish colonies in Guinea (Africa), Tranquebar (India) and the West Indies (Insular Central America). At that time, Denmark held some colonial settlements (collectively known as Danske Gulkyst or Dansk Guinea), which endured from 1661 to 1850, along the coast of what is now Ghana (Weiss, 2013), so we can effectively affirm that Lund's specimens from "Guinea" came from present day Ghana. Lyneborg et al. (2015) further restricted the type locality to the city of Teshie.

In Loew's (1848: 120) description of E. cilitarsis it reads "angeblich Oestreich" [="supposedly Austria"], and he added: "ich erhielt in derselben Sendung und unter derselben Vaterlandsangabe einige brasilianische Insekten, kann also die Richtigkeit derselben nicht verbürgen; die Nadel glich denen, mit welchen mehrere der notorisch europäischen Insekten gespiesst waren." [= "I have received in the same shipment and under the same country name some Brazilian insects, so I cannot guarantee the correctness [of the origin]; the pin resembled those with which many of the notorious European insects were pinned"]. Loew received the specimen, which he described as E. cilitarsis, together with some Brazilian and some European species - all of them supposed to be from Austria. The pin resembled the European specimens but recognizing that this is a mixed batch of species from different parts of the world, he had some doubts about the origin of this specimen. He did not

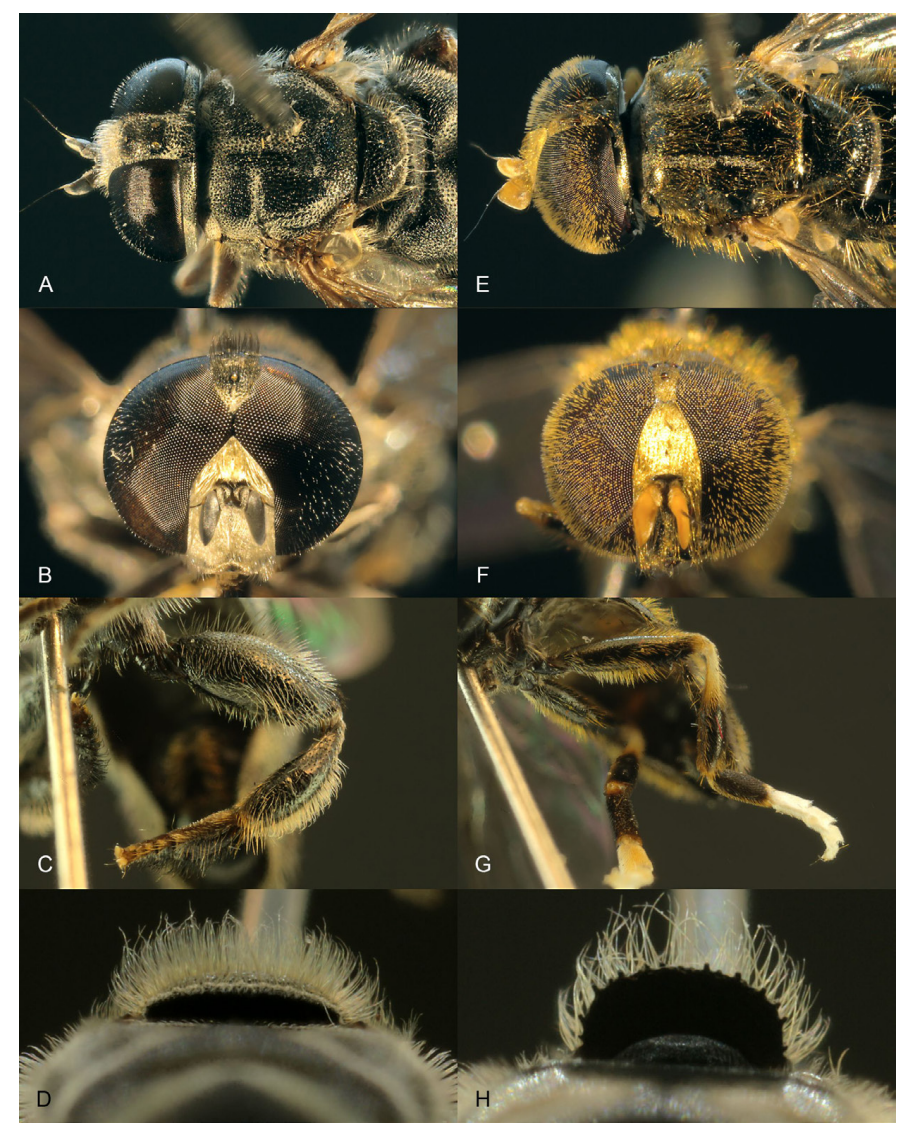

Figure 2. A-H. Eumerus species. A-D Eumerus obliquus (Fabricius). E-H Eumerus aurifrons (Wiedemann). A, D, H Female. B, C, E-G Male. A, E Head and thorax in dorsal view. B, F Head in frontal view. C, G Hind leg in anterior view. D, H Scutellum in postero-ventral view. mention from whom he received the insects and what other species were in the shipment and therefore we can only speculate about the material. It is more than likely that the material was not well labeled, and it represented a collection of mixed origin, including at least Brazilian and European material. It is very unlikely that the holotype of $E$. cilitarsis was collected in Austria, and it is also very unlikely that this species was collected in Brazil, where it is not native. The most likely explanation is that the specimen came from Africa without having a label, and it was given by an insect collector to Loew together with some other insects (likely Diptera).

Since the oldest collecting record in Brazil (1990 in Morretes, State of Paraná), this species has been spreading $700 \mathrm{~km}$ eastward and $1000 \mathrm{~km}$ northward across Brazil and entering Paraguay, where it was found as early as 2011, as far as collecting records had shown (Fig. 3).

\section{Eumerus aurifrons (Wiedemann)}

Pipiza aurifrons Wiedemann, 1824. Type locality: 'W. India' (Lectotype ZMUC00024836: http://daim.snm.ku.dk/digitized-type-collectiondetails?catno=zmuc00024836).

Eumerus albipes Keiser, 1971. Type locality: Madagascar, Nosy Be, Ambanoro. Holotype, male: 'Nosy Be: Ambanoro, 15.5.58 (F. Keiser)' (MNHN - Paris ?); Paratypes, 3 females (NMB); 'Ost-Madagaskar: Mananjary (Fia.), 6.viii.58, Ile Saint-Marie. (F. Keiser)' (Allotype); 'West Madagaskar: Ankarafantsika (Maj.), 18.vi.58. (F. Keiser)'; 'Ost-Madagaskar: Ile Sainte-Marie, Ambatoroa, v.59 (in. coll. I.R.S.M., Razafimandiby)'.

Distribution: ASIA: India, Indonesia, Philippines; AFRICA: Ghana, Madagascar, Nigeria, Tanzania; OCEANIA: Australia, Hawaii. SOUTH AMERICA: Paraguay* (Bigot, 1892; Paramonov, 1957; Smith and Vockeroth, 1980; Ôhara and Kusigemati, 1985; Mitra et al., 2015; Thompson and Vockeroth, 2016).

Material examined: PARAGUAY: San Pedro: Choré, XII.2016-I.2017, from beans plot (FCA) [1 female: MNHNPY; 1 female: CEUFLA]; Paraguarí: Parque Nacional Ybycuí, 18.VIII.2018 (B. Garcete) [1 male: MNHNPY].

Illustrations: Both female (Fig. 1D) and male (Fig. 1E) are illustrated. Characters to separate it from Eumerus obliquus are the abdominal pattern, (Fig. 1F), as well as the pattern of mesonotal pollinosity (Fig. 2E). Males have the eyes dichoptic (Fig. 2F) and the hind tarsus is dorsoventrally flattened, enlarged and covered in silver reflecting

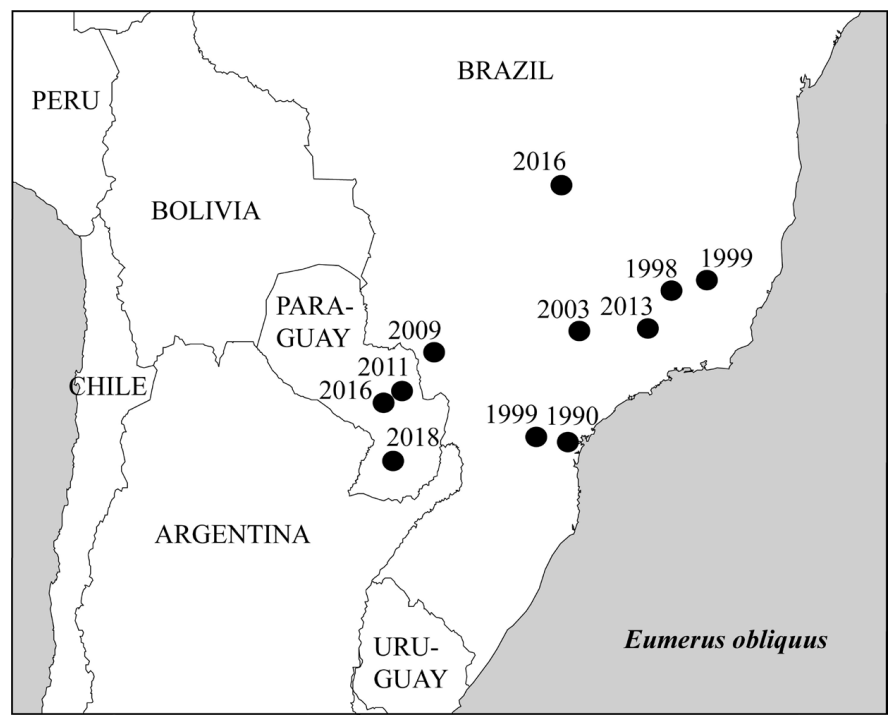

Figure 3. Eumerus obliquus (Fabricius) locations in South America indicating the collecting years for each one. 
setae (Fig. 2G). In the female the scutellar rim is clearly, albeit shortly, serrate (Fig. $1 \mathrm{H})$.

Comments: Eumerus aurifrons was originally described from India and its presence there has been corroborated by records from several places across the subcontinent by subsequent authors (Bigot, 1892; Mitra et al., 2015). Nevertheless, we should note that at least the record of this species from West Bengal by Sengupta et al. (2018), based on a single specimen, is a missidentification, as the specimen depicted in their Fig. 1D clearly shows a different species, probably Eumerus figurans Walker. The finding of specimens of E. aurifrons in Paraguay represents the first record of this species in the Americas.

Key to the introduced species of Eumerus in the Americas and Hawaii

While E. figurans, E. obliquus and E. aurifrons are very distinct and easy to identify by external morphology, the other three species (E. funeralis, E. strigatus and E. narcissi) are very similar and more difficult to distinguish. This is especially true for the females, while the males can be identified with certainty by examining the sternite 4 and the male genitalia. The following papers have illustrations of the male genitalia: E. narcissi (Smith, 1928; Speight et al., 2013), E. funeralis (partially under its synonymous name $E$. tuberculatus: (Smith, 1928; Vujić and Šimić, 1998; Grković et al., 2017), E. obliquus (DeMoor, 1973), E. strigatus (Smith, 1928; Vujić and Šimić, 1998; Grković et al., 2017).

1. Scutellum rectangular with chitin on the posterior margin white, nearly translucent (Fig. 4A); robust larger species; widespread in SE Asia, introduced to Hawaii

figurans Walker, 1859

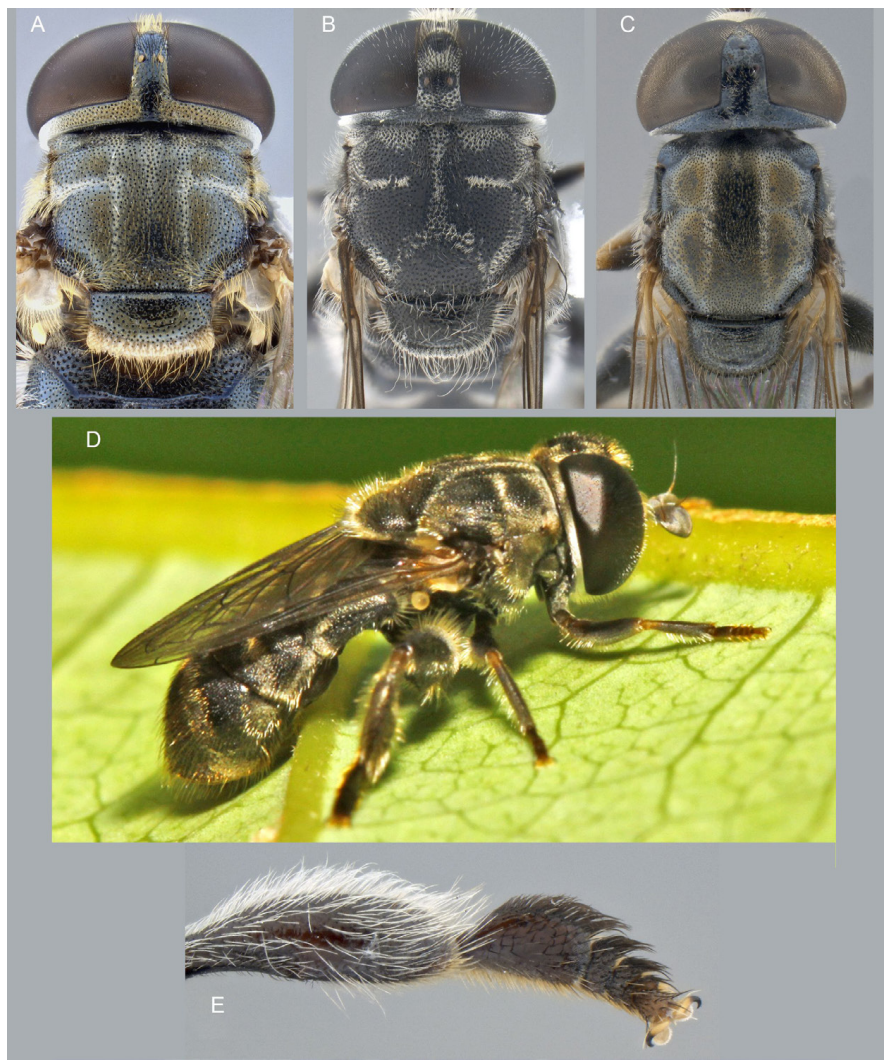

Figure 4. A-E. Eumerus species, males. A Eumerus figurans Walker. B, D, E Eumerus obliquus (Fabricius). C Eumerus strigatus(Fallen). A-C Head and thorax in dorsal view. D Living individual from Laguna Blanca, Paraguay [copyright J. Smit]. E Hind tibia and tarsus.
- Scutellum trapezoid or rounded, chitin completely black, often with metallic reflections (Fig. 4C), sometimes with a white margin, which consist of short dense microtrichia along the hind margin (Fig. 4B) 2

2. Scutellum with narrow margin of short dense white setae (Fig. 4B); male hind tarsus, and (tarsomeres 2-4) laterally compressed forming a crest, which is covered with stiff black erect setae (Fig. 4E); widespread in Africa, in Europe known from the Canary isles, Corfu and Sardinia, introduced into Australia, Brazil and Paraguay ...

.obliquus Fabricius, 1805

- Scutellum completely black, often with metallic reflections (Fig. 4C); male hind tarsus often swollen (typical for the genus), but without such modifications (Figs. 5A and 5D)

3. Tergites 2 and 3 with yellowish white spots (Fig. 1F); eyes with very abundant peg-like ommatrichiae, which are golden in males and white in females (Figs. 2E and 2F); male eyes dichoptic, by the distance equals to the distance of the hind ocelli (Fig. 2F); male hind tarsomeres 2-5 dorsoventrally flattened, enlarged and covered in silver reflecting setae (Fig. 2G); widespread in SE Asia, introduced to Australia, Madagascar, Hawaii and Paraguay ...

aurifrons Wiedemann, 1824

- Tergites 2 and 3 without yellowish white spots, only with transverse white dusted markings (Fig. 1C); eyes with less dense, always white ommatrichiae, sometimes nearly bare (Fig. 4C); male eyes holoptic (Fig. 4C); hind tarsus not dorsoventrally flattened, nor covered with silver reflecting setae (Figs. 5A and 5D)

4. Base of hind femur with a ventro-basal projection (Fig. 5A); female tergite 5 with a distinct baso-lateral ridge (Fig. 5B); Widespread in the Western Palaearctic, introduced into North America and New Zealand

funeralis Meigen, 1822

- Base of hind femur without a ventro-basal projection (Fig. 5D); female tergite 5 without a distinct baso-lateral ridge (Fig. 5C) ...5

5. Distance from hind ocelli to posterior margin of head less than twice that to the front ocellus (Fig. 5F); Widespread in the Palaearctic region, Chile, North America, New Zealand, Australia

strigatus (Fallen, 1817)

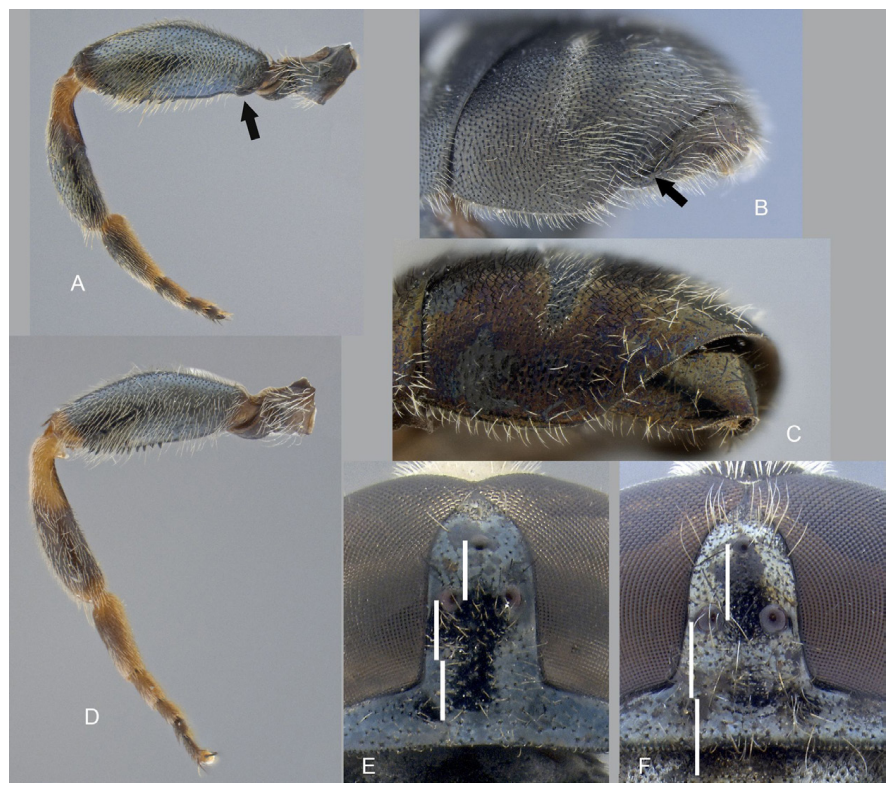

Figure 5. A-F. Eumerus species. A, B Eumerus funeralis Meigen. C, E Eumerus narciss Smith. D, F Eumerus strigatus (Fallen). A, D-F Male. B, C Female. A, D Hindleg [arrow indicates ventro-basal projection]. B, C Posterior visible abdominal tergites [arrow indicates ridge on tergite 5]. E, F Vertex of head in dorsal view [bars indicating distance between posterior ocellus and margin of head is more than twice the distance of anterior to posterior ocelli]. 
- Distance from hind ocelli to posterior margin of head more than twice that to the front ocellus (Fig. 5E); Europe and California ... narcissi Smith, 1928

\section{Acknowledgements}

To Dr Snežana Radenković (University of Novi Sad, Serbia) for confirming the identity of E. aurifrons, Dr Seraina Klopfstein (Naturhistorisches Museum Basel, Switzerland) for providing pictures of E. albipes, Dr José Roberto Pujol Luz (DZUB), Dr Kirstern Lica Follmann Haseyama (CCT-UFMG) and Dr Luciane Marinoni (DZUP) for borrowing E. obliquus specimens. MN Morales was supported by Coordination for the Improvement of Higher Education Personnel (CAPES), Brazil (proc. PNPD 20131282).

\section{Conflicts of interest}

The authors declare no conflicts of interest.

\section{Compliance with ethical standards}

The specimens were collected in accordance to national legislation and its regulatory resolutions, Ley 96/92 de Vida Silvestre, and part of the material is deposited in the Museo Nacional de Historia Natural del Paraguay as imposed by the law.

\section{Author contribution statement}

BRGB, LG, MBRDL, OA, MA, GS, AM conceived the research and conducted the fieldwork. BRGB, MNM, MH, JTS wrote the paper and contributed equally, all authors critically reviewed the manuscript. All authors approved the final version of this paper.

\section{References}

Asquith, A., Messing, R. H., 1993. Contemporary hawaiian insect fauna of a lowland agricultural area on Kaua'i: implications for local and island-wide fruit fly eradication programs. Pac. Sci. 47, 1-16.

Barkemeyer, W., 2002. Zur Syrphidenfauna der Kapverdischen Inseln (Diptera: Syrphidae). Mitt. Intern. Ent. Vereins. 27, 9-28.

Bigot, J. M. F., 1892. Catalogue of the Diptera of the Oriental region. Part II. J. Asiat. Soc. Bengal 2, 133-236. https://doi.org/10.5962/ bhl.title.9296.

Carter, W., 1968. Notes and exhibitions: Eumerus figurans (Walker). Proc. Hawaii. Entomol. Soc. 20, 15-16.

DeMoor, F. C., 1973. Notes on a syrphid fly, Eumerus obliquus (Fabricius) (Diptera: syrphidae). Arnoldia Rhod. 15, 1-7.

Fabricius, J. C., 1805. Systema Antliatorum: Secundum Ordines, Genera, Species, Adiectis Synonymis, Locis, Observationibus, Descriptionibus. Carolum Reichard, Brunsvigae. https://doi.org/10.5962/bhl.title.15806

Fullaway, D. T., Krauss, N. L. H., 1945. Common Insects of Hawaii. Tongg Publishing Company, Honolulu, Hawaii.

Gerding, M., Cisternas, E., Aguilera, A., Apablaza, J., 1999. Eumerus strigatus(Fallen) (Diptera: Syrphidae) infestando Alliaceae en Chile. Agric. Téc. 59, 133-135.

Gibson, A., 1917. The occurence of Eumerus strigatus Fln. in Canada. Can. Entomol. 49, 190-191. https://doi.org/10.4039/Ent49190-6.

Grković, A., Vujić, A., Chroni, A., Van Steenis, J., Đana, M., Radenković, S., 2017. Taxonomy and systematics of three species of the genus Eumerus
Meigen, 1822 (Diptera: Syrphidae) new to southeastern Europe. Zool. Anz. 270, 176-192. https://doi.org/10.1016/j.jcz.2017.10.007.

Grković, A., Vujić, A., Radenković, S., Chroni, A., Petanidou, T., 2015. Diversity of the genus Eumerus Meigen (Diptera, Syrphidae) on the eastern Mediterranean islands with description of three new species. Ann. Soc. Entomol. Fr. 51, 361-373. https://doi.org/10.108 0/00379271.2016.1144483.

Johnson, C. W., 1910. Some additions to the dipteran fauna of New England. Psyche. 17, 228-235. https://doi.org/10.1155/1910/67813.

Jones, C. R., 1917. New species of Colorado Syrphidae. Ann. Entomol. Soc. Am. 10, 219-231.

Kuznetzov, S., 1992. A new Palaearctic species and a new female of the genus Eumerus Meigen (Diptera, Syrphidae). Int. J. Dipterological Res. 3, 33-40.

Loew, H., 1848. Ueber die europäischen Arten der Gattung Eumerus. Entomol. Zeitung 9, 108-128.

Lyneborg, L., Pape, T., Thompson, F. C., 2015. New afrotropical eumerine flower fly synonyms (Diptera: syrphidae). Entomol. Mon. Mag. 151, 117-124.

Mackie, D. B., 1922. Note on the lesser bulb or lunulate fly (Eumerus strigatus Fallen). Mon. Bull. Dep. Agric. State Calif. 11, 759.

Marinoni, L., Morales, M. N., 2007. The second record of the genus Eumerus Meigen, 1822 (Diptera: Syrphidae) for the Neotropical Region and the first for Brazil. Proc. Entomol. Soc. Wash. 109, 493-495.

Miranda, G. F. G., Young, A. D., Locke, M. M., Marshall, S. A., Skevington, J. H., Thompson, F. C., 2013. Key to the genera of Nearctic Syrphidae. Can. Arthropod Identif. 23, 1-351. https://doi.org/10.3752/cjai.2013.23.

Mitra, B., Roy, S., Imam, I., Ghosh, M., 2015. A review of the hover flies (Syrphidae: Diptera) from India. Int. J. Fauna Biol. Stud. 2, 61-73.

Montoya, A. L., 2016. Family Syrphidae. Zootaxa 4122, 457-537. https:// doi.org/10.11646/zootaxa.4122.1.39.

Morales, M. N., Marinoni, L., 2019. Syrphidae. In: Jardim Botânico do Rio de Janeiro (Ed.), Catálogo taxonômico da fauna do Brasil. PNUD, Rio de Janeiro. Available in: http://fauna.jbrj.gov.br/fauna/ faunadobrasil/827 (accessed 30 October 2019).

Ôhara, K., Kusigemati, K., 1985. Syrphidae of Solomon Islands and Fiji (Insecta, Diptera). Kagoshima Univ. Res. Center S. Pac. Occas. Pap. 5, 81-86.

Paramonov, S. J., 1957. Notes on Australian Diptera (XXIV). Ann. Mag. Nat. Hist. 10, 125-128. https://doi.org/10.1080/00222935708655938.

Peck, L. V., 1988. Family Syrphidae. In: Soós, A., Papp, L. (Eds.), Catalogue of Palaearctic Diptera. Syrphidae - Conopidae. Vol. 8. Akadémiai Kiadó, Budapest, pp. 11-230.

Ricarte, A., Souba-Dols, G. J., Hauser, M., Marcos-García, M. A., 2017. A review of the early stages and host plants of the genera Eumerus and Merodon(Diptera: Syrphidae), with new data on four species. PLoS One 12, e0189852. https://doi.org/10.1371/journal.pone.0189852.

Sengupta, J., Naskar, A., Maity, A., Homechaudhuri, S., Banerjee, D., 2018. Distributional scenario of hover flies (Diptera: Syrphidae) from the state of West Bengal. Munis Entomol. Zool. 13, 447-457.

Smit, J. T., Van Harten, A., Ketelaar, R., 2017. The hoverflies from the Arabian Peninsula. In: Van Harten, A. (Ed.), Arthropod Fauna of the UAE 6. Dar Al Ummah Printing, Publishing, Distribution \& Advertising, Abu Dhabi, pp. 572-612.

Smith, K. G. V., Vockeroth, J. R., 1980. 38. Family Syrphidae. In: Crosskey, R.W.(Ed.), Catalogue of the Diptera of the Afrotropical Region. British Museum (Natural History), London, pp. 488-510.

Smith, L. M. 1928. Distinction between three species of Eumerus (Syrphidae, Diptera), with description of a new species. Pan-Pac. Entomol. 4, 137-139.

Speight, M. C. D., Hauser, M., Withers, P., 2013. Eumerus narcissi Smith (Diptera, Syrphidae), presence in Europe confirmed, with a redescription of the species. Dipterists Dig. 20, 17-32. 
Thompson, F. C., 2018. Syrphidae. Systema Dipterorum. Version 2.4. 13,431 records. Available in: http://sd.zoobank.org/ (accessed 30 October 2019).

Thompson, F. C., Vockeroth, J. R., 2016. Family Syrphidae. In: Evenhuis, N.L. (Ed.), Catalog of the Diptera of the Australasian and Oceanian Regions (Online Version). Bishop Museum Special Publication, Honolulu, pp. 437-458. Available in: http://hbs.bishopmuseum. org/aocat/syrphidae.html (accessed 30 October 2019).

Thompson, F. C., Vockeroth, J. R., Sedman, Y. S., 1976. Family Syrphidae: A Catalogue of the Diptera of the Americas South of the United States. Departamento de Zoologia, Secretaria de Agricultura, São Paulo.

Vujić, A., Šimić, S., 1998. Genus Eumerus Meigen, 1822 (Diptera: Syrphidae) in area of former Yugoslavia. Bull. Nat. Hist. Mus. Belgr. 49, 173-190.

Weiss, H., 2013. The Danish Gold Coast as a Multinational and Entangled Space, c. 1700-1850. In: Naum, M., Nordin, J.M. (Eds.), Scandinavian Colonialism and the Rise of Modernity: Small Time Agents in a Global Arena. Springer, New York, pp. 243-260.
Weiss, H. B., Nicolay, A. S., 1919. Eumerus strigatus Fall., the lunate onion fly, in New Jersey (Dipt.). Entomol. News 30, 27.

Whittington, A. E., 2003. The Afrotropical Syrphidae fauna: an assessment. Stud. Dipterologica 10, 579-607.

Wirth, W. W., Sedman, Y. S., Weems Junior, H. V., 1965. Family Syrphidae. In: Stone, A., Sabrosky, C.W., Wirth, W.W., Foote, R.H., Coulson, J.R. (Eds.), A Catalog of the Diptera of America North of Mexico. United States Department of Agriculture, Washington, pp. 557-624.

Young, A. D., Lemmon, A. R., Skevington, J. H., Mengual, X., Ståhls, G., Reemer, M., Jordaens, K., Kelso, S., Moriarty Lemmon, E., Hauser, M., De Meyer, M., Misof, B., Wiegmann, B. M., 2016. Anchored enrichment dataset for true flies (order Diptera) reveals insights into the phylogeny of flower flies (family Syrphidae). BMC Evol. Biol. 16, 1-13. https://doi.org/10.1186/s12862-016-0714-0.

Zimsen, E., 1964. The Type Material of I. C. Fabricius: Winds Bogtrykkeri, Haderlslev. Munksgaard, Copenhagen. 